\title{
Wiedza pielęgniarek pracujących w oddziałach internistycznych na temat terapii bólu w chorobach nowotworowych
}

\author{
The knowledge of nurses working in internal wards on pain \\ treatment in cancer disease
}

\author{
BEATA CHOJNACKA, GRAŻYNA CHOJNACKA-KOWALEWSKA²
1Zespół Szkół Technicznych we Włocławku, Wojewódzki Szpital Zespolony im. Rydygiera w Toruniu, Oddział Kliniczny Nefrologii, Diabetologii i Chorób Wewnętrznych
${ }^{2}$ Państwowa Uczelnia Zawodowa, Instytut Nauk o Zdrowiu, Wojewódzki Szpital Specjalistyczny we Włocławku, Oddział Medycyny Paliatywnej

DOI: https://dx.doi.org/10.21784/IwP.2019.019

ISSN: 2451-1846

\section{Streszczenie:}

Wstęp. Choroba nowotworowa jest jednym z najważniejszych problemów współczesnej medycyny. Objawem prawie każdego etapu tej choroby jest ból, który definiowany jest jako nieprzyjemne doznanie czuciowe i emocjonalne, związane rzeczywistym lub potencjalnym uszkodzeniem tkanek, a także opisywane w kategoriach takiego uszkodzenia. Z symptomem tym spotykamy się u $66 \%$ chorych w terminalnym stadium, u 55\% osób podczas leczenia onkologicznego i u 39\% ozdrowieńców. Dlatego też, posiadanie wiedzy na temat jego łagodzenia powinno stać się priorytetem dla osób uczestniczących w procesie leczenia.

Cel. Celem pracy jest ocena poziomu wiedzy pielęgniarek z zakresu terapii bólu nowotworowego.

Materiał i metody. Badaniem objęto 48 pielęgniarek pracujących na Oddziale Klinicznym Nefrologii, Diabetologii i Chorób Wewnętrznych Szpitala Wielospecjalistycznego w Toruniu. 100 \% respondentów stanowiły kobiety. Badania przeprowadzono w miesiącu lutym 2018 roku, zostały one 
wykonane metodą sondażu diagnostycznego. Analizowano czy poziom wiedzy zależy od stażu pracy, wykształcenia. Sprawdzano, czy badani postępują zgodnie $\mathrm{z}$ przyjętymi procedurami oraz czy biorą udział $\mathrm{w}$ szkoleniach $\mathrm{z}$ zakresu terapii bólu nowotworowego. Wykorzystano technikę ankiety, a informacje zostały zebrane za pomocą kwestionariusza ankiety, który skonstruowano na rzecz prowadzonych badań. Analizę statystyczną przeprowadzono za pomocą współczynnika korelacji R Spearmana oraz Testu U Manna - Whitneya.

Wyniki. Umiejętność definiowania bólu wykazało 39,6\% respondentów, a 35,7\% badanych wskazało skalę numeryczną jako najczęściej wykorzystywane narzędzie do oceny natężenia bólu nowotworowego. 50\% badanych pielęgniarek prowadzi karty kontroli bólu. Według 26,4\% respondentów indywidualne dobieranie dawek i leków to najważniejsza zasada leczenia bólu. Leki I szczebla drabiny analgetycznej potrafi scharakteryzować $45,8 \%$ badanych. Respondenci w średnim stopniu znali uboczne objawy ze strony układu pokarmowego spowodowane przez leki opioidowe (33,9\% wskazało zaparcia). Badani w 87,5\% znali definicję leków adjuwantowych. Dla 38,5\% za najważniejszą cechę bólu przebijającego wskazało jego charakter napadowy. Na poszerzenie i utrwalanie wiedzy na temat leczenia bólu poprzez udział $\mathrm{w}$ szkoleniach i samokształcenie wskazało $77,1 \%$ respondentów. Poziom wiedzy pielęgniarek z zakresu zasad leczenia bólu $\mathrm{w}$ chorobie nowotworowej jest średni. Wynik nie jest uzależniony od czynników zawodowych.

Wnioski. 1. Czynnikiem, który nie ma wpływu na poziom wiedzy z zakresu leczenia bólu nowotworowego jest staż pracy. 2. Badania nie wykazały zależności między wykształceniem, posiadanymi kwalifikacjami, a reprezentowanym poziomem wiedzy. 3. Tylko połowa ankietowanych oceniając ból nowotworowy postępuje zgodnie z przyjętymi procedurami opracowanymi przez szpital. 4. Personel uczestniczy w szkoleniach z zakresu leczenia bólu nowotworowego, jednak w znacznej mierze są to szkolenia wewnątrzszpitalne.

Słowa kluczowe: ból nowotworowy, pielęgniarki, wiedza 


\begin{abstract}
:
Introduction. Cancer is one of the most significant problems of modern medicine. The symptom of almost every stage of this disease is pain, which is defined as unpleasant sensory and emotional sensation associated with real or potential tissue damage and also described in terms of such damage. We encounter this symptom in $66 \%$ of cases of terminally ill people $1,55 \%$ of people treated oncologically and $39 \%$ of convalescents. This is why the knowledge of pain relief should become a priority for people who take part in the process of treatment.
\end{abstract}

Aim. The aim of the study was to measure the level of nurse's knowledge in the field of cancer pain therapy.

Material and Methods. The study included 48 nurses working in Clinical Ward of Nephrology, Diabetology and Internal Medicine of the Multi Specialist Hospital in Torun. $100 \%$ of the respondents were women. The study was conducted in February 2018 and it used a diagnostic survey. It was analysed if the level of knowledge depends on professional experience and education. It was checked whether the respondents followed established procedures and if they take part in the pain therapy trainings. The survey method was used and the data was collected using the survey questionnaire constructed for the sake of the research. Statistical analysis was carried out using the R. Spearman rank correlation coefficient and the Mann-Whitney U test.

Results. $39,6 \%$ of the respondents showed the ability to define pain, $35,7 \%$ of the respondents indicated a numeric scale as the most often used tool available to rate the intensity of the cancer pain. $50 \%$ of the nurses surveyed keep the pain cards. $26,4 \%$ of the respondents consider the individual selection of doses and medicines as the most important principle in pain treatment. The first level drugs in the analgesic ladder can be recognized by $45,8 \%$ of the respondents. The respondents were moderately familiar with gastrointestinal side effects caused by opioid drugs $33,9 \%$ indicated constipation). $87,5 \%$ of the respondents knew the definition of adjuvant drugs. For 38,5\% the most significant feature of breakthrough pain was its paroxysmal nature. Expanding and consolidating the knowledge of treating pain by taking part in trainings and self-education was indicated by $77,1 \%$ of 
the respondents. The level of the nurses' knowledge in terms of treating pain principles is moderate. The result is not dependent on professional factors.

Conclusion. 1. The factor that does not affect the level of knowledge in the field of pain treatment is work experience. 2 . The research did not show the relationship between education, qualifications held and the level of knowledge. 3. Only half of the respondents while describing cancer pain proceed with established procedures developed by the hospital. 4 . The staff attends the training of cancer pain treatment, but to a large extent, these are in-hospital trainings.

Keywords: cancer pain, nurses, knowledge

\section{Wstęp}

Ból nie zna granic wiekowych i towarzyszy nam od pierwszych dni życia. Każdy z nas doświadczył, co najmniej jednego epizodu bólu. Ból w chorobie nowotworowej jest doświadczany całościowo, bardzo osobiście i odmiennie przez każdego chorego. Według definicji zaproponowanej przez Międzynarodowe Towarzystwo Badania Bólu (International Association for the Study-IASP), ból to nieprzyjemne doznanie czuciowe i emocjonalne, związane $\mathrm{z}$ rzeczywistym lub potencjalnym uszkodzeniem tkanek, a także opisywane w kategoriach takiego uszkodzenia[1].. Wpływa on bezpośrednio na jakość życia każdego pacjenta, ogranicza aktywność, wymusza zmianę przyzwyczajeń i otoczenia. Zakłóca także funkcjonowanie fizycznej i psychicznej sfery ludzkiego organizmu. Ból to cierpienie całej osobowości pacjenta. Biorąc pod uwagę wieloprzyczynowość bólu, każdy pacjent powinien być leczony według indywidualnego planu, co wymaga zarówno ze strony lekarza jak i pielęgniarki wiedzy medycznej jak i pozamedycznej, by móc zapewnić podstawowe prawo pacjenta do życia w godności[2]. Częstość występowania bólu u chorych $\mathrm{z}$ chorobą nowotworową jest oceniana na około $55 \%$ podczas leczenia onkologicznego, $66 \% \mathrm{u}$ chorych $\mathrm{w}$ terminalnym 
okresie choroby a także u 39\% ozdrowieńców[3]. Właściwa ocena bólu i jego monitorowanie a także znajomość patofizjologii i metod leczenia są niezbędne skutecznego postepowania w terapii bólu[4].

Pielęgniarka jako członek zespołu terapeutycznego winna posiadać szeroką wiedzę $\mathrm{z}$ zakresu oceny i leczenia bólu nowotworowego. Niezmiernie ważne jest, aby pielęgniarka, która towarzyszy chorym na każdym etapie ich choroby, szybko dokonała oceny sytuacji, podjęła odpowiednie decyzje o doborze środków do zniwelowania bólu oraz monitorowała efekty leczenia. Wiedza, doświadczenie, przestrzeganie procedur są niezbędne w sprawowaniu holistycznej opieki nad chorym, a zapewnienie skutecznego postępowania przeciwbólowego jest niezbywalnym prawem każdego pacjenta i równocześnie podstawowym obowiązkiem zarówno lekarza jak i pielęgniarki. Profesjonalna i kompetentna pielęgniarka może być przewodnikiem dla pacjenta na jego drodze leczenia bólu nowotworowego.

\section{Cel pracy}

Celem niniejszej pracy jest ocena poziomu wiedzy pielęgniarek z zakresu terapii bólu nowotworowego.

\section{Materiał i metody}

Badaniem objęto 48 pielęgniarek pracujących na Oddziale Klinicznym Nefrologii, Diabetologii i Chorób Wewnętrznych Szpitala Wielospecjalistycznego w Toruniu. $100 \%$ respondentów to kobiety. Średnia wieku badanych wynosiła 49,9 lat. Najliczniejszą grupę stanowiły badane w wieku powyżej 50 lat $(41,7 \%)$ oraz osoby w przedziale 46 - 50 lat (31,2\%). Najmniejszą grupę liczyły osoby w wieku do 45 lat $(27,1 \%)$. Badaną grupę przeanalizowano pod kątem wykształcenia. Największy odsetek badanych stanowiły pielęgniarki ze średnim wykształceniem - 45,8\%. Wyższe wykształcenie posiadało 
$16,7 \%$ badanych. Kursy specjalistyczne i dokształcające ukończyło $44,8 \%$ badanych, kursy kwalifikacyjne $12,1 \%$. Średni staż pracy w zawodzie pielęgniarki wynosił 27,9 lat. Staż pracy na oddziale wewnętrznym powyżej 25 lat wskazało 18 pielęgniarek, co stanowiło $37,55 \%$ badanych. Natomiast $31,3 \%$ badanych osób miało staż pracy krótszy niż 15 lat. Badania przeprowadzono w miesiącu lutym 2018 roku. Zostały one wykonane metodą sondażu diagnostycznego. Wykorzystano technikę ankiety, a informacje zostały zebrane za pomocą kwestionariusza ankiety, który skonstruowano na rzecz prowadzonych badań. Analizowano czy poziom wiedzy zależy od stażu pracy, wykształcenia. Sprawdzano, czy ankietowani postępują zgodnie $\mathrm{z}$ przyjętymi procedurami oraz czy biorą udział $\mathrm{w}$ szkoleniach $\mathrm{z}$ zakresu terapii bólu nowotworowego. Kwestionariusz ankiety zawierał 31 pytań w tym 7 pytań dotyczyło danych podstawowych respondentów. Analizę statystyczną przeprowadzono za pomocą współczynnika korelacji R Spearmana oraz Testu U Manna - Whitneya.

\section{Wyniki}

Uczestniczenie w procesie uśmierzania bólu wymusza umiejętność jego zdefiniowania. I tak, jedno z pytań było pytaniem otwartym i należało w nim zdefiniować ból.

Najwięcej badanych określając definicję bólu stwierdziło, że są to: doznania zmysłowe $\mathrm{i}$ emocjonalne związane $\mathrm{z}$ działaniem uszkadzającego bodźca lub bodźców, którego działanie zagraża wystąpieniem takiego uszkodzenia - 19 osób (39,6\%). W dalszej kolejności wskazywali, że są to: subiektywne, negatywne wrażenie zmysłowe i emocjonalne pod wpływem bodźców - 6 osób (12,5\%).

Kolejne z pytań odnosiło się do znajomości skal (narzędzi) służących do oceny natężenia bólu. I tak, badane zaznaczały po kilka stwierdzeń. 


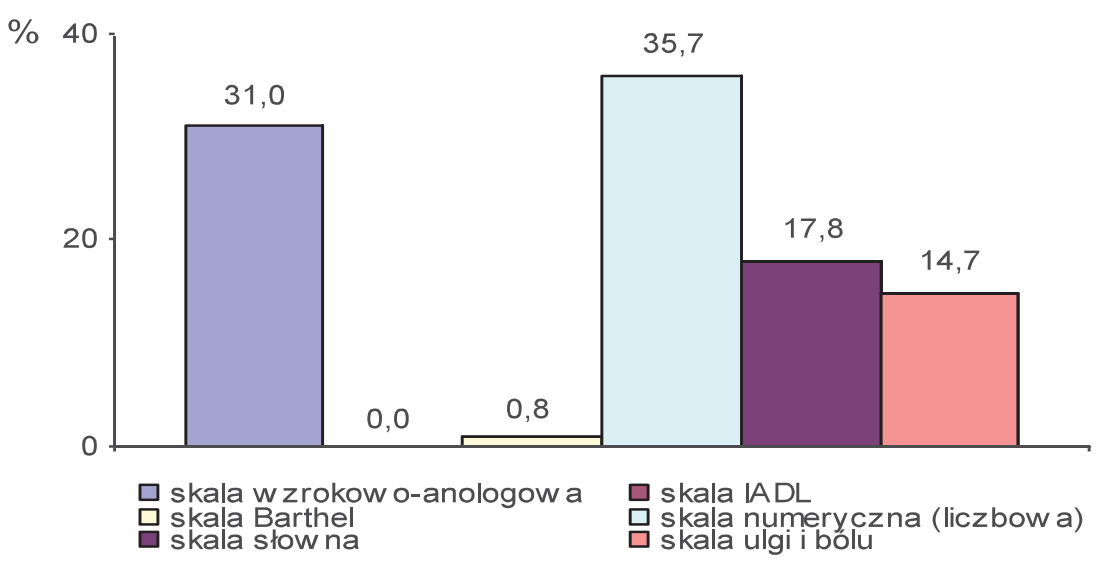

Rycina 1. Rozkład narzędzi (skali) służących do oceny natężenia bólu nowotworowego.

Źródło: wynik badań własnych

$\mathrm{Na}$ pytanie dotyczące prowadzenia kart kontroli bólu. Dokładnie połowa badanych wskazała, że je prowadzi.

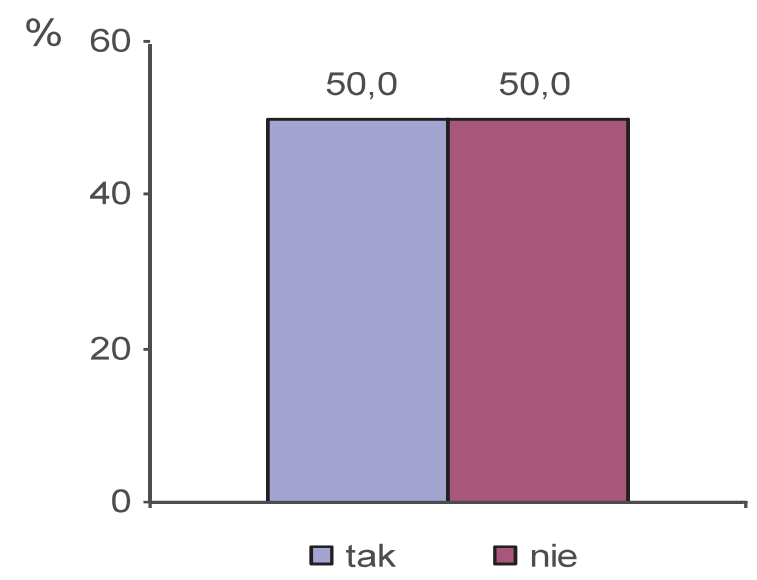

Rycina 2. Rozkład prowadzenia w pracy karty kontrolowania bólu wykorzystujące skale do oceny ból.

Źródło: wyniki badań własnych 
Pytanie dotyczące zdefiniowania bólu przebijającego było z kategorii otwartych. Analizowane pielęgniarki najczęściej charakteryzowały go jako ostry, gwałtowny, narastający, szybko przemijający - 8 osób $(16,7 \%)$. W dalszej kolejności wskazywały, że jest to: ból nagle pojawiający się i trwający krótko - 7 osób $(14,6 \%)$ oraz że, jest to ból mogący pojawiać się samoistne, na krótki czas, narasta, trwa krótko - 5 osób $(10,4 \%)$.

Wiedzę na temat bólu przebijającego sprawdzono także za pomocą pytania wielokrotnego wyboru, z którego respondenci mieli wybrać charakterystyczne cechy tegoż bólu.

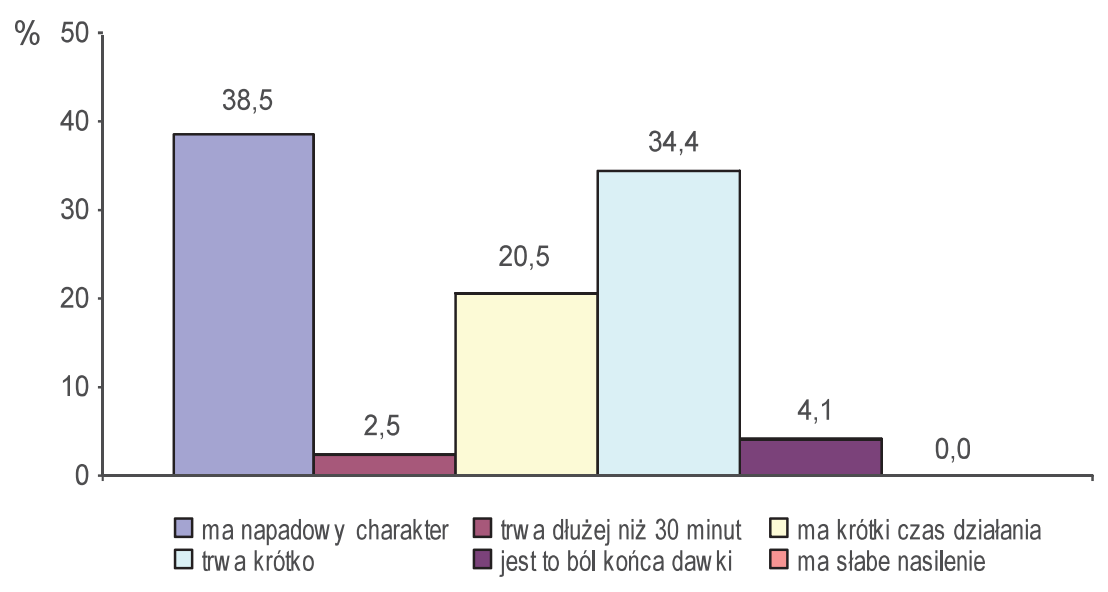

Rycina 3. Rozkład charakterystycznych cech bólu przebijającego. Źródło: wyniki badań własnych

Najwięcej badanych wskazało, że ma napadowy charakter - 47 osób, co stanowiło 38,5\% wszystkich zaznaczonych stwierdzeń. W dalszej kolejności wskazywały, że trwa krótko - 42 osoby $(34,4 \%)$ oraz ma krótki czas działania - 25 osób (20,5\%). Najmniej badanych wskazało, że trwa dłużej niż 30 minut - 3 osoby (2,5\%). Na jedną 
cechę bólu przebijającego wskazała - 1 osoba, na dwie cechy - 24 osoby, na trzy cechy - 19 osób oraz na cztery cechy - 4 osoby.

Ważnym elementem procesu opieki nad chorym z bólem nowotworowym jest znajomość zasad leczenia tego bólu. Spośród 48 ankietowanych pielęgniarek tylko 7 wybrało maksymalną liczbę zasad. Najrzadziej zaznaczanymi zasadami były: współdecydowanie przez chorego o drodze podawania leku. Za najważniejszą zasadę respondenci uznali indywidualne dobieranie dawki i leku $(26,4 \%)$ oraz regularne jego podawanie $(22,4 \%)$.

Kolejne pytanie miało uzyskać informacje na temat cech charakteryzujących miejsce przyklejenia plastra $\mathrm{z}$ analgetykami. Respondenci odpowiadając na to pytanie zaznaczali po kilka stwierdzeń. Najwięcej badanych wskazało, że miejsce to powinno być nieowłosione - 34 osoby, co stanowiło 31,2\% wszystkich zaznaczonych stwierdzeń. W dalszej kolejności wskazywali na płaską powierzchnię - 25 osób (22,9\%) oraz na miejsce bez zmian zapalnych - 19 osób (17,4\%). Najmniej badanych wskazało, że należy zmieniać miejsce przyklejania plastra, nie przyklejać bezpośrednio na tkanki kostne, nie przyklejać na okolicy piersiowej oraz prawidłowo ocieploną skórę - po 1 osobie (po 0,9\%). Na jedną cechę wskazały 3 osoby, na dwie cechy - 31 osób, na trzy cechy - 12 osób oraz na cztery cechy -2 osoby. 


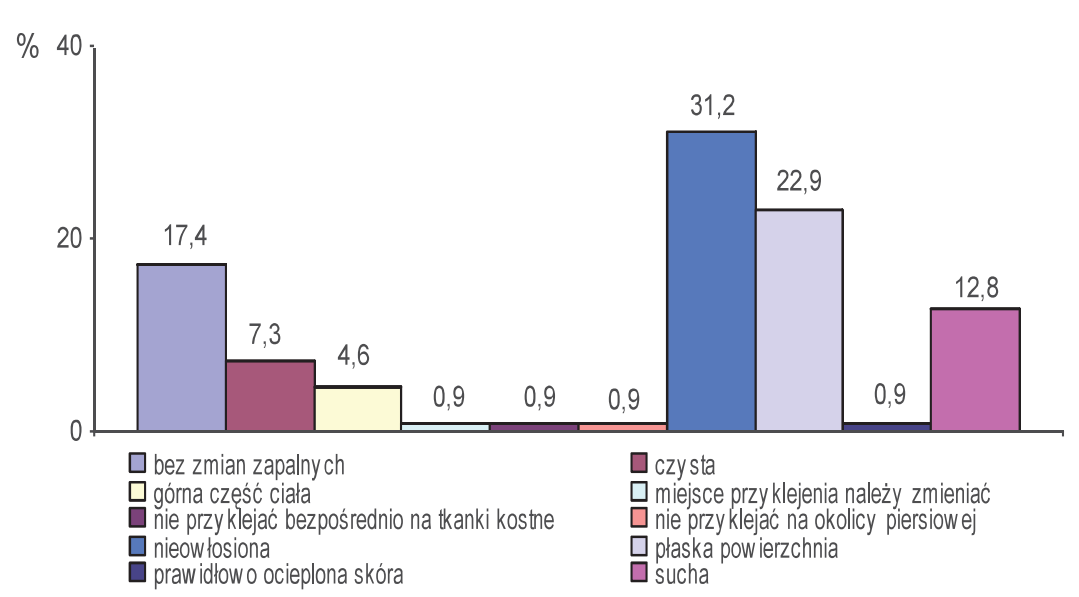

Rycina 4. Rozkład cech charakteryzujących miejsce przyklejania plastra $\mathrm{z}$ analgetykami.

Źródło: wyniki badań własnych

Jednym z pytań było pytanie wielokrotnego wyboru, w którym respondenci mogli wybrać zasady jakimi kierują się podczas leczenia bólu nowotworowego. Najwięcej badanych stwierdziło, że, leki przeciwbólowe i jego dawki dobiera się indywidualnie dla każdego chorego - 46 osób, co stanowiło 26,4\% wszystkich zaznaczonych stwierdzeń. W dalszej kolejności twierdzili, że doboru analgetyków dokonuje się wg tzw. drabiny analgetycznej - 40 osób (23\%) oraz leki przeciwbólowe podaje się regularnie, w ściśle określonych godzinach, aby utrzymać stały poziom leku w organizmie chorego - 39 osób $(22,4 \%)$. Najmniej badanych wskazało, że o drodze podawania leku współdecyduje pacjent - 12 osób (6,9\%). Na jedną zasadę wskazały 3 osoby, na dwie zasady - 2 osoby, na trzy zasady - 14 osób, na cztery zasady - 21 osób, na pięć zasad - 7 osób oraz na sześć zasad 1 osoba. 


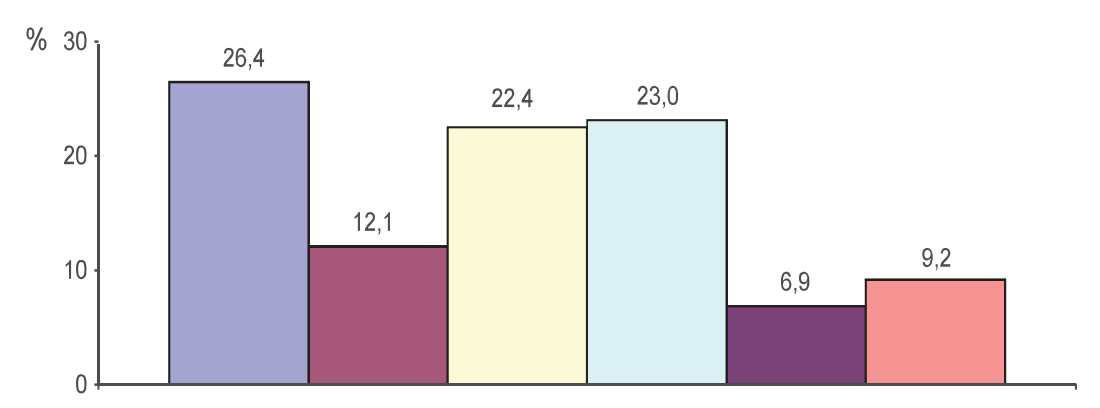

$\square$ leki przeciw bólowe i jego daw ki dobiera się indy widualnie dla każdego chorego

- leki przeciw bólowe podaje sie w razie wystapienia bólu i ży czenia pacjenta

leki przeciwbólowe podaje się regularnie, w sciśle określony ch godzinach aby utzzy mać stały poziom leku w organizmie chorego

$\square$ doboru analgetyków dokonuje się $w g$ tzw. drabiny analgety cznej

0 drodze podaw ania leku współdecy duje pacjent

$\checkmark$ leki przeciw bólow e powinny być podaw ane drogą doustną tak długo jak to jest możliwe

\section{Rycina 5. Rozkład zasad stosowanych podczas leczenia bólu nowotworowego.}

Źródło: wyniki badań własnych

Sprawdzano, także wiedzę na temat leków znajdujących się na I szczeblu drabiny analgetycznej. 22 osoby co stanowiło 45,8 \% ankietowanych wskazało, że do I szczebla drabiny analgetycznej zalicza się: analgetyki nieopioidowe, leki łagodzące działania niepożądane, natomiast 17 osób $(35,4 \%)$ wskazało na analgetyki nieopioidowe, koanalgetyki, leki łagodzące działania niepożądane. Najmniej stwierdziło, że słabe opioidy, analgetyki nieopioidowe, koanalgetyki, leki łagodzące działania niepożądane - 1 osoba $(2,1 \%)$. 


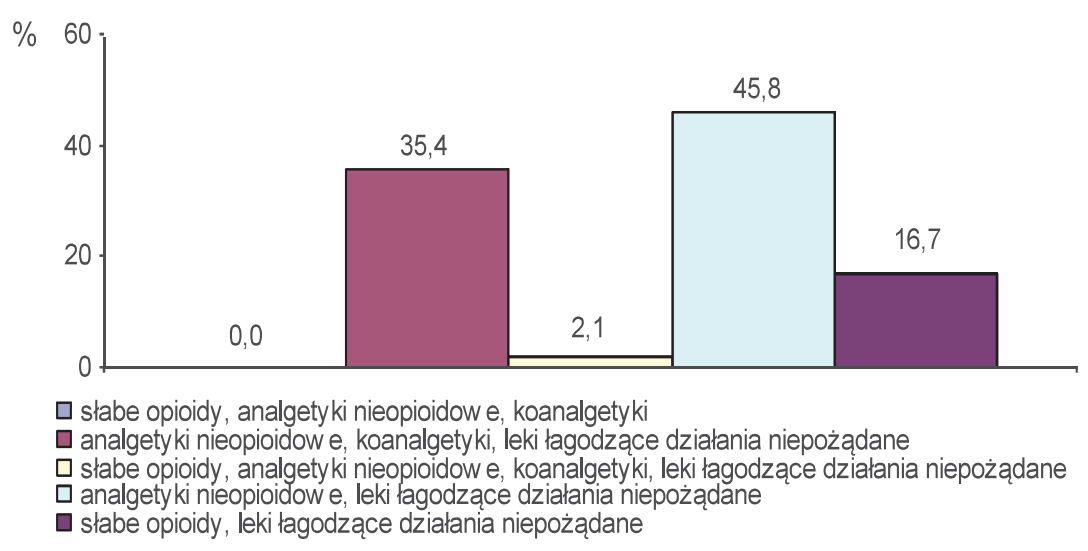

\section{Rycina 6. Rozkład leków zaliczanych do I szczebla drabiny analgetycznej.}

Źródło: wyniki badań własnych

Jedno z pytań badało umiejętność wskazania niepożądanych objawów leków przeciwbólowych ze strony układu pokarmowego. Najwięcej badanych wskazało, że objawem tym są zaparcia - 46 osób, co stanowiło 33,3\% wszystkich zaznaczonych stwierdzeń. W dalszej kolejności wskazywali na suchość jamy ustnej - 42 osoby $(30,4 \%)$ oraz na nudności i wymioty - 39 osób (28,3\%). Najmniej badanych wskazało na puste odbicia oraz ślinotok - po 1 osobie (po $0,7 \%$ ). Na dwa objawy wskazało - 11 osób, na trzy objawy - 33 osoby, na cztery objawy - 3 osoby oraz na pięć objawów - 1 osoba. 


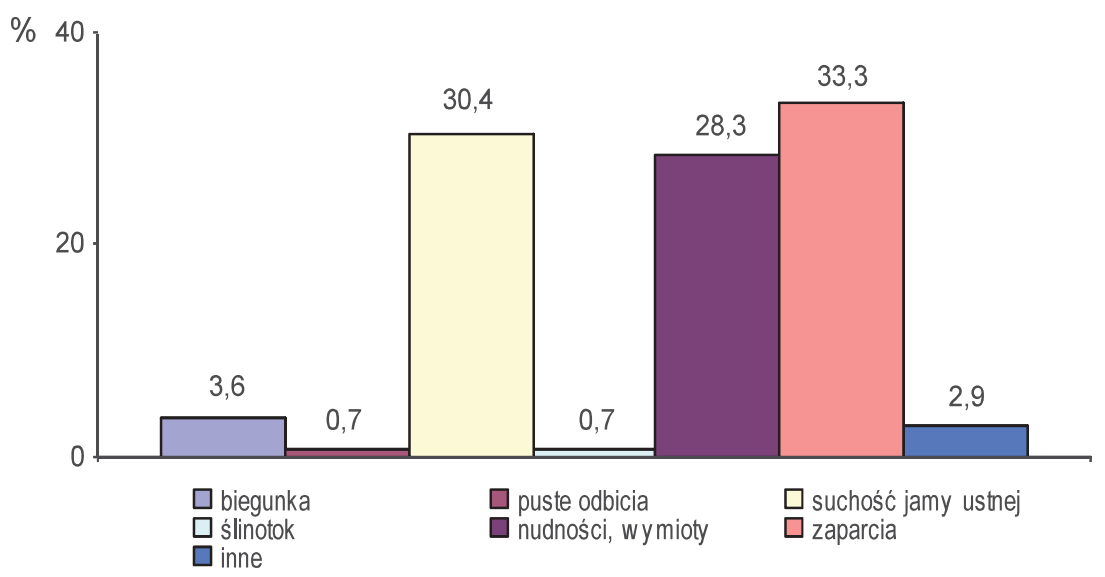

Rycina 7. Rozkład najczęściej występujące uboczne działania opioidowych leków przeciwbólowych ze strony układu pokarmowego.

Źródło: wyniki badań własnych

Zdecydowana większość respondentów (87,5\%) stwierdziła, że leki adjuwantowe stosowane w leczeniu bólu to leki, które nie należą do grupy leków przeciwbólowych, ale stwierdzono ich działanie przeciwbólowe w różnych rodzajach bólu - 42 osoby $(87,5 \%)$. Dodatkowo jedna z osób wskazała, że są to leki, należące do grupy NLPZ. Najmniej stwierdziło, że są to leki, które wykazują typowe działanie przeciwbólowe i leki, które obniżają próg odczuwania bólu po 1 osobie (po 2,1\%). 


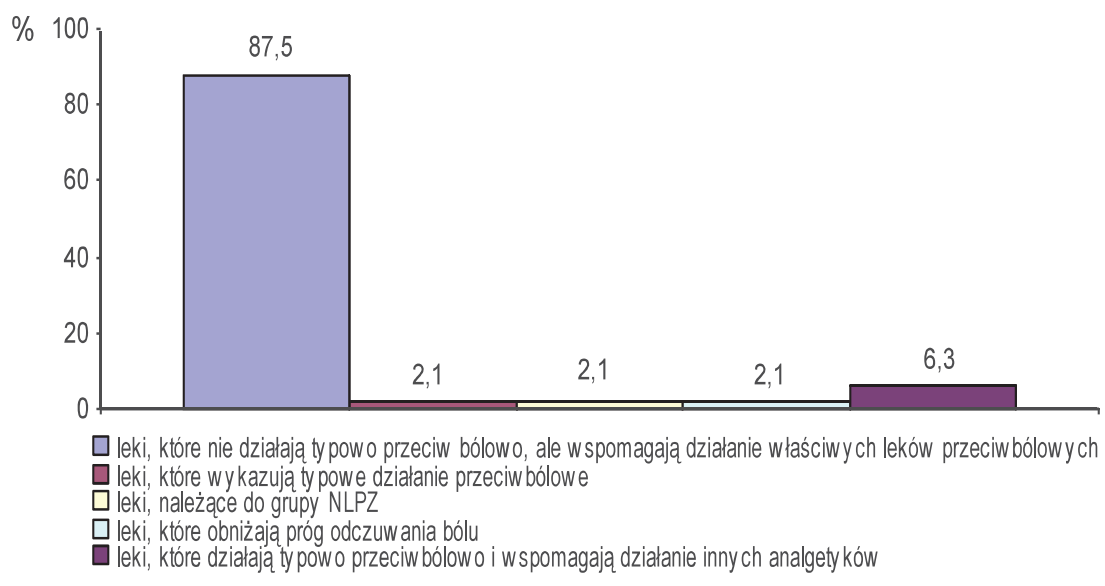

Rycina 8. Rozkład rozumienia pojęcia leki adjuwantowe stosowane w leczeniu bólu.

Źródło: wyniki badań własnych

Ankietowani wskazywali duże zróżnicowanie poziomu wiedzy na temat dróg podawania morfiny. Pytanie to było kolejnym z kategorii wielokrotnego wyboru. Najczęściej wskazywaną odpowiedzią była droga doustna $(24,9 \%)$. W dalszej kolejności wskazywali na podawanie dożylne - 47 osób $(24,4 \%)$ oraz na podawanie przezskórne - 29 osób $(15,0 \%)$. Najmniej badanych wskazało, na podawanie doodbytnicze 10 osób $(5,2 \%)$ oraz domięśniowe - 6 osób $(3,1 \%)$. Na dwie drogi podawania morfiny wskazały - 4 osoby, na trzy drogi - 9 osób, na cztery drogi - 22 osoby, na pięć dróg - 10 osób, na sześć dróg - 2 osoby i na osiem dróg podawania morfiny wskazała - 1 osoba. 


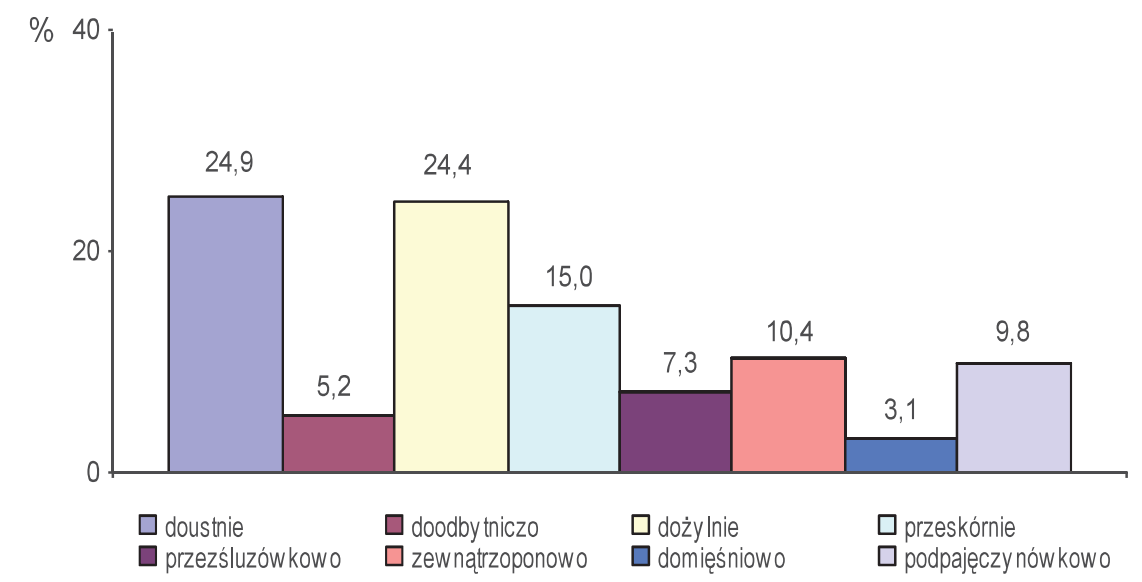

\section{Rycina 9. Rozkład dróg podawania morfiny.}

Źródło: wyniki badań własnych

Analizowano, także wiedzę pielęgniarek odnośnie czynników wpływających na progu bólu. Najczęściej wskazywanym czynnikiem było umiejscowienie bólu - 15 osób, co stanowiło 10,4\% wszystkich zaznaczonych stwierdzeń. W dalszej kolejności wskazywali, na lęk, tolerancję bólu - po 12 osób (po 8,3\%) oraz na płeć - 11 osób $(7,6 \%$ ). Najmniej badanych wskazało na: brak wiary w pomyślność terapii, charakter bólu, choroby współistniejące, długość leczenia, emocje, odpoczynek, psychiczne izolacje, stopień zaawansowania choroby oraz wysiłek fizyczny - po 1 osobie (po 0,7\%). Na dwa czynniki wpływające na próg bólu wskazały - 3 osoby, na trzy czynniki - 41 osób na cztery czynniki - 3 osoby.

$\mathrm{Na}$ pytanie, czy ankietowani biorą udział w szkoleniach dotyczących leczenia bólu nowotworowego - 31 osób (77,1\%) odpowiedziało, że tak. Natomiast na pytanie jakiego typu są to szkoleń. Badane najczęściej zaznaczały szkolenia wewnątrzoddziałowe - 18 osób, co stanowiło 40,0\% wszystkich zaznaczonych stwierdzeń. 
W dalszej kolejności wskazywały na szkolenia organizowane przez Izby Pielęgniarskie - 8 osób $(17,8 \%)$. Najmniej wskazań było na szkolenia prowadzone przez firmy farmaceutyczne - 1 osoba $(2,2 \%)$. Pod pojęciem „inne” odnotowano: Internet, literaturę bądź studia licencjackie i magisterskie. Na jeden rodzaj szkoleń wskazało 31 osób, na dwa rodzaje - 5 osób oraz na cztery rodzaje - 1 osoba.

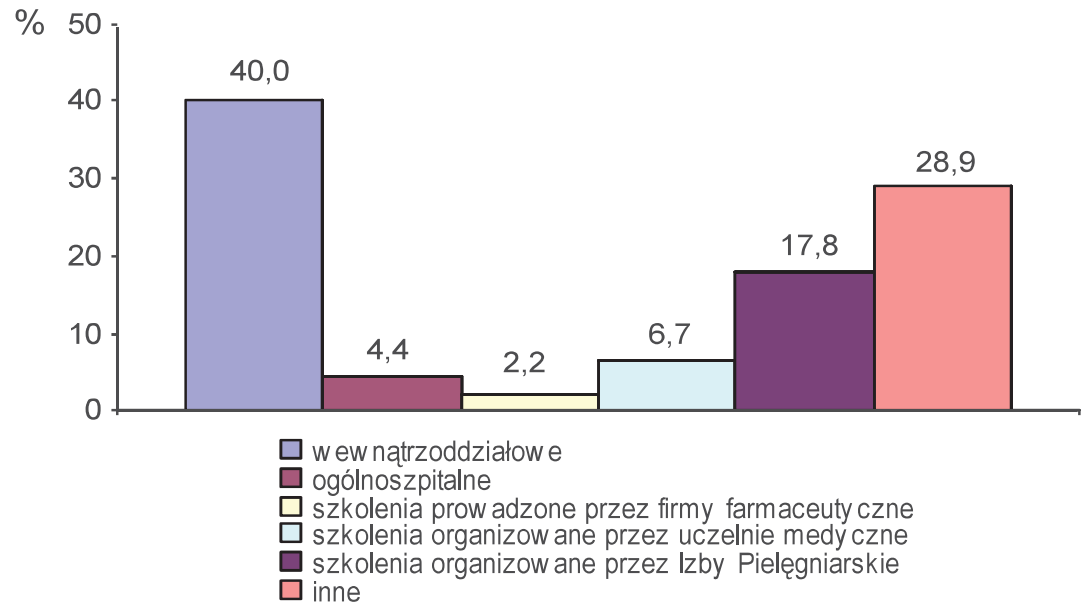

\section{Rycina 10. Rozkład udziału w szkoleniach dotyczących leczenia} bólu.

Źródło: wyniki badań własnych

Analiza wyników badań własnych wykazała, że pielęgniarki pracujące na oddziale wewnętrznym nie wykazują szerokiego zasobu wiedzy z zakresu leczenia bólu nowotworowego. Oceniając poziom wiedzy poddano ocenie punktowej wybrane pytania kwestionariusza. Maksymalnie można było uzyskać 28 pkt, gdzie minimalny wynik, który wyznacza wysoki poziom wiedzy nie powinien być niższy niż 22 pkt. Wyniki powyższych badań oceniają wiedze pielęgniarek z zakresu 
leczenia bólu nowotworowego w punktacji ogólnej 17,5 punktów, czyli na poziomie średnim.

\section{Dyskusja}

Oddział internistyczny zajmuje się schorzeniami narządów wewnętrznych. Zakres diagnozowanych i leczonych chorób jest szeroki. Nie ulega wątpliwości, że pracując na oddziale wewnętrznym, każdy zetknął się z bólem u chorego nowotworowego. Pielęgniarka w zespole terapeutycznym odgrywa istotną rolę w opiece nad chorym, gdyż ma bezpośredni i najczęstszy z nim kontakt. Miarą skutecznego pielęgnowania będzie zapewnienie warunków godnego życia $\mathrm{z}$ bólem, dlatego opieka nad chorym wymaga wiedzy i umiejętności praktycznych z wielu dziedzin nauki.

Jedna $\mathrm{z}$ hipotez zakładała, że poziom wiedzy powinien być uzależniony od stażu pracy, gdyż pracując zdobywamy doświadczenia. Ankietowanych podzielona na trzy grupy wiekowe. W każdym przedziale poziom wiedzy mieścił się $\mathrm{w}$ granicach wartości średniej. Najwyższy poziom wiedzy odnotowano $\mathrm{w}$ grupie ze stażem pracy w zawodzie pielęgniarek 26-30 lat, najniższy wśród badanych ze stażem powyżej 30 lat. Podczas badań własnych, stwierdzono, że staż pracy na oddziale wewnętrznym nie ma wpływu na poziom wiedzy. Wyniki badań własnych nie potwierdzają się $\mathrm{z}$ wynikami przeprowadzonych badań przez Rezmerska, gdzie wykazano, że czynnikiem wpływającym na zakres wiedzy pielęgniarek i jej wykorzystanie w terapii bólu u pacjentów Oddziału Anestezjologii i Intensywnej Terapii jest ogólny staż pracy w zawodzie i staż pracy w Oddziale Anestezjologii. Przyczyną rozbieżności wyników jest specyfika oddziału oraz stosowanie standardów związanych $\mathrm{z}$ uśmierzaniem bólu[5].

Ból jest przykrym, osobistym odczuciem. Pełni funkcję informacyjną, a jednocześnie generuje szereg negatywnych emocji. 
Efektywne jego rozpoznanie i leczenie umożliwiają choremu lepiej przeżyć kolejny dzień. Człowiek dzięki uczeniu się zdobywa nowe umiejętności i poszerza wiedzę. Ankietowani przygotowanie do wykonywanego zawodu uzyskali kończąc liceum, studium medyczne, studia wyższe lub magisterskie. Analiza statystyczna wykazała, że każda badana grupa charakteryzuje się średnim poziomem wiedzy zakresu leczenia bólu nowotworowego. Wysoki poziom wiedzy uzyskały 2 z 22 pielęgniarek będących abiturientkami liceum pielęgniarskiego, co stanowi $9,1 \%$ natomiast 1 pielęgniarka z 10 $(10 \%)$ z wykształceniem wyższym. Ze względu na poziom istotności p>0,05 nie zaobserwowano istotnej statystycznie zależności pomiędzy wykształceniem ankietowanych, a poziomem prezentowanej wiedzy w przygotowaniu do leczenia bólu. Wyniki badań własnych różnią się od wyników uzyskanych $\mathrm{w}$ badaniach przeprowadzonych przez Rezmerską i wsp., gdzie analiza statystyczna wykazała istotną zależność pomiędzy wykształceniem, a poziomem wiedzy. 95\% respondentek z wykształceniem wyższym wykazało wysoki poziom wiedzy, a ponad $61 \%$ ankietowanych wykształceniem średnim medycznym średni poziom wiedzy [5].

W badaniach własnych nie zaobserwowano większej wiedzy wśród pielęgniarek, które podnosiły swoje kwalifikacje zawodowe poprzez ukończenie kursów doskonalących, a pozostałymi ankietowanymi. Uzyskany poziom wiedzy w obu grupach jest średni. Poziom ten reprezentuje $77,1 \%$ pielęgniarek posiadających kwalifikacje i 76,8\% pielęgniarek bez kwalifikacji. Nie odnotowano istotnej statystycznie zależności pomiędzy posiadanymi kwalifikacjami, a poziomem wiedzy pielęgniarek $(p>0,05)$. Powyższe badania porównano z badaniami. Rezmerska i wsp., gdzie znaczna większość ankietowanych wykazała wysoki poziom wiedzy niezależnie od posiadanych kwalifikacji. Również i w tych badaniach $\mathrm{w}$ analizie 
statystycznej nie zaobserwowano istotnej zależność pomiędzy kwalifikacjami zawodowymi, a poziomem wiedzy[5].

Autorzy badań przeprowadzonych przez Knap i wsp. poddali analizie udział pielęgniarek $\mathrm{w}$ szkoleniach $\mathrm{z}$ zakresu leczenia bólu. Stwierdzono, że $50 \%$ badanych uczestniczyło w szkoleniach wewnątrzszpitalnych[6]. Taki sam wynik uzyskano podczas badań przeprowadzonych przez Rezmerską[5]. Wyniki badań własnych wykazują, że 77,1\% ankietowanych bierze udział w szkoleniach. Wynik ten można uznać za niewystarczający. Pielęgniarki głównie (44\%) uczestniczą w szkoleniach wewnątrzszpitalnych (wewnątrzoddziałowych i ogólnoszpitalnych). Wydaje się, że są to szkolenia za mało profesjonalne, aby umożliwiły pełnienia istotnej roli w zespole terapeutycznym w zakresie leczenia bólu.

Jednym z podstawowych praw człowieka jest prawo do ulgi w cierpieniu. Pielęgniarka, aby skutecznie uśmierzyć ból i przez to zwiększyć satysfakcję pacjenta powinna podjąć działania zgodne z obowiązującymi w szpitalu procedurami, instrukcjami oceny i leczenia bólu. Podczas badań własnych stwierdzono, że 47,9\% respondentów wie, że w szpitalu są opracowane procedury dotyczące leczenia bólu, 27,1\% twierdzi, że ich nie ma, a 25\% nie wie. Pielęgniarka jest rzecznikiem i przewodnikiem pacjenta na jego trudnej drodze leczenia i aby w pełni funkcję tę zrealizować winna m. in. działać według standardów postępowania przeciwbólowego przyjętych w szpitalu. Chory ma prawo do tego, aby go nie bolało.

Pielęgniarki pracujące na oddziale wewnętrznym wykazują średni poziom wiedzy z zakresu leczenia bólu nowotworowego. $\mathrm{W}$ badaniach B. Wrona, poziom wiedzy pielęgniarek $\mathrm{z}$ zakresu aktualnych wytycznych leczenia bólu w chorobie nowotworowej jest zadawalający[7]. Na uzyskanie takiego wyniku ma fakt przeprowadzenia badań wśród pielęgniarek onkologicznych. Uzyskane 
różnice badań uzależnione są od charakteru pracy i profilu sprawowanej opieki na oddziale onkologicznym i nieonkologicznym.

\section{Wnioski}

Przeprowadzone badania uwidoczniły, że wśród ankietowanych brak satysfakcjonującej wiedzy na temat leczenia bólu.

1. Czynnikiem, który nie ma wpływu na poziom wiedzy z zakresu leczenia bólu nowotworowego jest staż pracy.

2. Badania nie wykazały zależności między wykształceniem, posiadanymi kwalifikacjami, a reprezentowanym poziomem wiedzy.

3. Tylko połowa ankietowanych oceniając ból nowotworowy postępuje zgodnie z przyjętymi procedurami opracowanymi przez szpital.

4. Personel uczestniczy $\mathrm{w}$ szkoleniach $\mathrm{z}$ zakresu leczenia bólu nowotworowego, jednak $\mathrm{w}$ znacznej mierze są to szkolenia wewnątrzszpitalne.

\section{Zalecenia dla praktyki pielęgniarskiej}

Wraz $\mathrm{z}$ rozwojem cywilizacji zwiększa się liczba pacjentów nowotworowych, także tych wyleczonych, którzy cierpią z powodu bólu przewlekłego. Dlatego też, znajomość zasad rozpoznawania, oceniania, monitorowania i leczenia bólu przez pielęgniarki jest niezbędna do zapewnienia pacjentom fundamentalnego prawa do życia bez bólu i uzyskania wysokiej jakości sprawowanej nad nimi opieki. Konieczny jest wysoki poziom kształcenia przeddyplomowego jak i podyplomowego z zakresu leczenia bólu nowotworowego. Istnieje także, potrzeba podjęcia działań edukacyjnych wpływających na wzrost poziomu wiedzy pielęgniarek w tym obszarze. 


\section{Bibliografia/Bibliography:}

1. Ciałkowska-Rysz A., Dzierżanowski T. Medycyna Paliatywna. Wydawnictwo Termedia, Poznań 2019:67.

2. Leppert W., Wordliczek J. Zalecenia postępowania diagnostycznoterapeutycznego u chorych na nowotwory $\mathrm{z}$ bólem. W: Leppert W., Wordliczek J. (red.) Onkologia w praktyce klinicznej. Wydawnictwo Via Medica 2018;4(1):1-2.

3. Wordliczek J. i wsp. Farmakologia bólu u chorych na nowotworyzalecenia Polskiego Towarzystwa badania Bólu, Polskiego Towarzystwa medycyny Paliatywnej, Polskiego Towarzystwa Onkologicznego, Polskiego Towarzystwa Medycyny Rodzinnej, Polskiego Towarzystwa Anestezjologii i Intensywnej Terapii. 2017;18(3):5.

4. Krajnik M. Zasady oceny bólu u chorego na nowotwór. W: MalecMilewska M., Krajnik M., Wordliczek J.(red.) Chory na nowotwór kompendium leczenia bólu. Medical Education. 2014;33-43.

5. Rezmerska L., Dulska I. Wiedza pielęgniarek i jej wykorzystanie w terapii bólu pooperacyjnego u pacjentów Oddziału Anestezjologii i Intensywnej Terapii. Innowacje w pielęgniarstwie i naukach o zdrowiu. 2017,1(2):71.

6. Knap M., Szyrmer B., Kowalczyk-Soroka B. Poziom wiedzy pielęgniarek z oddziałów zabiegowych na temat terapii bólu pooperacyjnego. Problemy Pielęgniarstwa. 2010;18(2)1:31-132.

7. Wrona B., Janecki M., Fimiarz A. Wiedza pielęgniarek na temat aktualnych wytycznych leczenia bólu w chorobie nowotworowej. Medycyna Paliatywna. 2014;6,(4):14.

Otrzymano: 25.04.2019r.

Zaakceptowano: $20.05 .2019 \mathrm{r}$.

\section{0 znaków}

